\title{
Treatment outcome of Philadelphia chromosome negative myeloproliferative neoplasms: experience of a single developing country's hematology-oncology centre
}

\author{
Mohammed Salim ${ }^{1}$, Zrari Salar ${ }^{2}$
}

1. College of Health Sciences, Hawler Medical University, Iraq.

2. College of Medicine, Hawler Medical University, Iraq.

\begin{abstract}
Background: Myeloproliferative neoplasms (MPNs) include polycythemia vera (PV), essential thrombocythemia (ET), and primary myelofibrosis (PMF) are characterized by excessive production of blood cells. Treatment of MPNs patients has an important effect thereby reducing morbidity and mortality.

Objective: To evaluate the effect of cytoreductive treatment on some hematological and biochemical parameters in MPNs patients treated at a hemato-oncology Centre in Erbil, Iraq.

Methods: A total of 185 patients diagnosed with PV, ET, and PMF (111 males and 74 females with a mean age of $50.8 \pm 3.2$ years, range: 46-73) were assigned to receive MPNs treatment. Laboratory tests were performed before and after a median period from the initiation of MPNs treatment of 9.3 months (range 5-10 months).

Results: Significant differences were noted in Hemoglobin $(\mathrm{P}<0.003)$, Hematocrit $(\mathrm{P}<0.004)$, Neutrophil $(\mathrm{P}<0.001)$ and glutamate pyruvate transferase levels $(\mathrm{P}<0.01)$ in $\mathrm{PV}$ patients, Platelet count $(\mathrm{P}<0.002)$ in ET patients, and both white blood cell count $(\mathrm{P}<0.004)$ and Lactate dehydrogenase level $(\mathrm{P} \& 1 ; 0.001)$ in PMF patients, while no significant differences were found in other parameters at the time of diagnosis and during therapy.

Conclusion: Clinical and laboratory improvements were presented in MPNs patients. Regular follow up of patients are essential to ensure prescribed treatment in addition to the continual and long-lasting response to therapy and to prevent thrombosis.

Keywords: Cytoreductive treatment, MPNs, JAK2 mutation.

DOI: https://dx.doi.org/10.4314/ahs.v19i3.21

Cite as: Salim M, Salar Z. Treatment outcome of Philadelphia chromosome negative myeloproliferative neoplasms: experience of a single developing country's hematology-oncology centre. Afri Health Sci. 2019;19(3): 2462-2467. https://dx.doi.org/10.4314/ahs. v19i3.21
\end{abstract}

\section{Introduction}

The classic myeloproliferative neoplasms (MPNs) include polycythemia vera (PV), essential thrombocythemia (ET), and primary myelofibrosis (PMF). They are characterized by excessive terminally differentiated myeloid cells ${ }^{1}$, when there is a need for myelosuppression, the antineoplastic activity has been increasingly used, based on inhibition of the ribonucleotide reductase enzyme and hence the DNA synthesis is inhibited ${ }^{2}$. Currently, this is the most frequently prescribed drug for the treatment of MPNs

\section{Corresponding author: \\ Mohammed Salim, \\ College of Health Sciences, \\ Hawler Medical University. \\ Email: salim.khalid@hmu.edu.iq}

worldwide and is considered as an essential medicine by the World Health Organization (WHO) with a broad dose response range, little mutagenic risk, and mild side effects $^{3}$.

Since 2005, the major interest has been generated in the Philadelphia chromosome-negative myeloproliferative neoplasms (MPNs) and anti-JAK2-targeted therapy4. Mutated Janus Kinase 2 (JAK2) V617F is found in approximately $95 \%$ of patients with PV, and about $50 \%$ of those with ET or $\mathrm{PMF}^{5}$.

Thus, MPNs are clinically heterogeneous diseases in which drugs are used to lower red blood cell (RBC), white blood cell (WBC), and Platelet (Plt) counts or to inhibit Plt function is often problematic ${ }^{6}$. Hydroxyurea $(\mathrm{HU})$ reduces the Plt count, thereby decreasing thrombotic episodes in patients with ET. Because of the proven efficacy

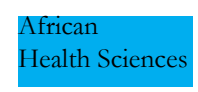

(C) 2019 Salim et al. Licensee African Health Sciences. This is an Open Access article distributed under the terms of the Creative commons Attribution License (https://creativecommons.org/licenses/BY/4.0), which permits unrestricted use, distribution, and reproduction in any medium, provided the original work is properly cited. 
of $\mathrm{HU}$ in MPNs treatment, HU has been used in clinical trials on a wide range of advanced $\mathrm{MPNs}^{7}$. These diseases are often accompanied by a profound clinical and laboratory profile that significantly reduces survival and quality of life of patients. In general, HU has been shown to reduce MPN-related symptoms including fatigue, night sweats, pruritus, concentration problems and splenomegaly, Additionally, it also reduces morbidity and mortality risk factors such as thrombotic events and fibrotic and/ or leukemic transformation ${ }^{8,9}$.

It has been noticed that therapeutic interventions focusing on hematological and biochemical levels are beneficial in the prevention of MPNs risk factors and symptoms. The correlation between JAK2 V617F mutation with laboratory and clinical features of the disease through MPNs treatments is interesting ${ }^{10}$.

Nowadays, after molecular identification of JAK2 V617F mutation in patients diagnosed for MPNs particularly PV, ET, and PMF are currently drawing scientific attention for JAK2 V617F mutation study and its potential influence on disease phenotype ${ }^{11}$.

Currently, the most important objectives are in slowing or delaying progression of disease and prevention of vascular/thrombotic events. Myelosuppressive drugs induce hematological responses in MPNs and can reduce splenomegaly, as well as relieve constitutional symptoms ${ }^{12}$.

A subset of patients in this study reported symptom relief as their most important treatment goal. The therapies that patients most often reported receiving at any time were phlebotomy 34(18.3\%), aspirin 41 (22.1\%), and HU $32(17.3 \%)$ in the PV patients; ASA 25 (13.5\%), and pegasys $24(12.9 \%)$ in ET patients; and aspirin $14(7.5 \%)$, ruxolitinib $5(2.7 \%)$ and HU $10(5.4 \%)$ in the PMF patients.

There is a lack of outcome data about MPNs patients who have been treated at our Centre. Consequently, the aim of the present study was to evaluate the effect of cytoreductive treatment on some hematological and biochemical parameters in MPNs patients treated at one Hemato-Oncology Centre in Erbil, Iraq.

\section{Methods}

\section{Blood patients}

This retrospective study had 185 consecutive patients with MPNs, (111 males and 74 females with a mean age of 50.8 \pm 3.2 years, range: 46-73), Patients were diagnosed and categorized into PV, ET, and PMF using revised WHO 2016 criteria $^{13}$, there were 107 patients with PV, 49 patients with ET, and 29 patients with PMF. These included both newly diagnosed cases $(n=41)$ and previously diagnosed cases on follow-up $(n=144)$. They were enrolled in the trial and treated for myelosuppression. Patients were excluded if they did not fulfill WHO criteria and if they did not attend follow-ups regularly. The study was conducted between October 2016 and July 2017.

From each individual, $5 \mathrm{ml}$ the blood samples were obtained. Patients were selected among those followed up in the hematology clinic at Nanakali Hospital for blood diseases and cancer in Erbil, Iraq and who were referred to the laboratory undergo hematological and biochemical tests. Blood samples were subjected to analysis for JAK2 V617F mutation using Amplification Refractory Mutation Screening Polymerase Chain Reaction ARMS-PCR technique ${ }^{14}$.

For data collection a case report form was prepared which is consisted of demographic features, patient characteristics, and laboratory data at the time of diagnosis and during therapy [after a mean duration of response was 9.3 months (range 5-10 months)]. The study was approved by the scientific advisory committee of the College of Medicine at Hawler Medical University and written informed consent was obtained from all patients before their inclusion in this study (Ethical no: 17 in 23/4/2016).

All patients recruited into the study were fully anonymized, and received the MPNs treatment. PV and ET patients were on ASA (aspirin: acetyl salicylic acid), Venesection (Phlebotomy), Pegasys (pegylated interferon-alfa-2a), HU (hydroxyurea), and Plavix, PMF patients were on Jakafi (ruxolitinib), Danazol (reduce pain), and Exjade (deferasirox; reduce iron) depending on the type and severity of the diseases. The starting dose of myelosuppressive drugs was subsequently modified according to the efficacy and tolerability in each patient.Therefore, a maintenance dose of the drugs was administered to maintain the laboratory results within normal ranges.

\section{Haematological parameters}

Blood counts were measured using autoanalyser. The PE600, fully auto Hematology Analyzer (China) was used, while Excite-40 ESR analyser was used to analyse ESR (Vital Diagnostics, USA). 


\section{Biochemical parameters}

Blood sodium, potassium, chloride and ionized calcium were measured simultaneously by OPTI LION Electrolyte auto analyzer in the same single-use cartridge. Moreover, other biochemical tests were estimated with fully automated chemical analyzer by using Cobas diagnostic kits (Roche/COBAS 311 INTEGRA, biochemical analyzer).

\section{Statistical analysis}

Data were expressed as the mean \pm the standard devi- ation SD, or as percentage frequencies. All calculations were made using (SPSS for windows version 19.0). Within patient comparisons were made using the student t-test for paired data, at a significance levels of $\mathrm{P}<0.0515$.

\section{Results}

The age range of the 185 evaluated patients was 46-73 years with a mean of $50.8 \pm 3.2$ years. Male patients were $60 \%(n=111)$ and female patients were $40 \%(n=74)$. The sample included 57.8\% $(\mathrm{n}=107)$ PV patients, $26.4 \%$ $(n=49)$ ET patients, and 15.6\% $(n=29)$ PMF patients, as shown in Table 1.

Table 1: Different variables of the studied groups.

\begin{tabular}{|l|c|c|c|c|}
\hline Variables & PV & ET & PMF & Total \\
\hline Number of patients & $107(57.8 \%)$ & $49(26.4 \%)$ & $29(15.6 \%)$ & 185 \\
\hline Age (year, mean \pm SD) & $49.7 \pm 2.3$ & $51.2 \pm 2.8$ & $54.3 \pm 4.3$ & $50.8 \pm 3.2$ \\
\hline Gender $(\%)$ & $75(70.7 \%)$ & $19(38.3 \%)$ & $17(58.8 \%)$ & $111(60 \%)$ \\
Male & $32(29.3 \%)$ & $30(61.7 \%)$ & $12(41.2 \%)$ & $74(40 \%)$ \\
Female & 22 & 19 & 11 & 52 \\
\hline $\begin{array}{l}\text { Number of patients } \\
\text { with splenomegaly }\end{array}$ & & & 11 & 5 \\
\hline
\end{tabular}

A total of 52 patients had splenomegaly at the start of therapy, and three patients underwent splenectomy for symptomatic splenomegaly.

At the end of the study period, the majority of the mean of the treatment.

Table (2): Hematological parameters at time of incidence and during MPNs therapy.

\begin{tabular}{|c|c|c|c|c|c|c|c|c|c|}
\hline \multirow[b]{2}{*}{ Variables } & \multicolumn{2}{|c|}{ PV } & \multirow[b]{2}{*}{$\begin{array}{c}P \\
\text { value }\end{array}$} & \multicolumn{2}{|c|}{ ET } & \multirow[b]{2}{*}{$\begin{array}{c}P \\
\text { value }\end{array}$} & \multicolumn{2}{|c|}{ PMF } & \multirow{2}{*}{$\begin{array}{c}P \\
\text { value }\end{array}$} \\
\hline & $\begin{array}{l}\text { At time of } \\
\text { diagnosis }\end{array}$ & $\begin{array}{l}\text { During } \\
\text { therapy }\end{array}$ & & $\begin{array}{l}\text { At time of } \\
\text { diagnosis }\end{array}$ & $\begin{array}{l}\text { During } \\
\text { therapy }\end{array}$ & & $\begin{array}{l}\text { At time of } \\
\text { diagnosis }\end{array}$ & $\begin{array}{c}\text { During } \\
\text { therapy }\end{array}$ & \\
\hline $\begin{array}{c}\mathrm{WBC} \\
\left(\mathrm{X} 10^{9} / \mathrm{L}\right. \\
\text { mean } \pm \mathrm{SD})\end{array}$ & $18.8 \pm 0.8$ & $10.1 \pm 0.59$ & 0.06 & $8.9 \pm 0.89$ & $10.1 \pm 0.99$ & 0.07 & $9.7 \pm 0.12$ & $8.3 \pm 0.26$ & 0.004 \\
\hline $\begin{array}{c}\mathrm{Hgb}\left(\mathrm{X} 10^{9} / \mathrm{L}\right. \\
\text { mean } \pm \mathrm{SD})\end{array}$ & $18.6 \pm 0.57$ & $14.4 \pm 0.03$ & 0.003 & $13.8 \pm 0.62$ & $13.2 \pm 0.72$ & 0.42 & $11.8 \pm 0.91$ & $12.7 \pm 0.06$ & 0.44 \\
\hline $\begin{array}{c}\mathrm{HCT}(\% \\
\text { mean } \pm \mathrm{SD})\end{array}$ & $59.3 \pm 2.53$ & $46.4 \pm 1.23$ & 0.004 & $46.3 \pm 2.63$ & $43.5 \pm 2.7$ & 0.46 & $35.1 \pm 2.0$ & $36.3 \pm 1.09$ & 0.43 \\
\hline $\begin{array}{c}\text { Plt }\left(\mathrm{X} 10^{9} / \mathrm{L}\right. \\
\text { mean } \pm \mathrm{SD})\end{array}$ & $\begin{array}{c}348.2 \pm 20 \\
8\end{array}$ & $394.1 \pm 15.8$ & 0.8 & $687.7 \pm 21.5$ & $400.4 \pm 24.0$ & 0.002 & $291 \pm 12.3$ & $251.2 \pm 8.9$ & 0.09 \\
\hline $\begin{array}{c}\text { Neutrophil } \\
(\%, \\
\text { mean } \pm \text { SD) }\end{array}$ & $79.7 \pm 3.39$ & $73.8 \pm 3.28$ & 0.001 & $82.0 \pm 2.24$ & $78.1 \pm 3.23$ & 0.72 & $76.3 \pm 3.49$ & $73.9 \pm 3.73$ & 0.41 \\
\hline $\begin{array}{c}\text { Lymphocyte } \\
(\%, \\
\text { mean } \pm \text { SD) }\end{array}$ & $14.7 \pm 1.41$ & $20.4 \pm 1.13$ & 0.11 & $12.4 \pm 1.51$ & $15.3 \pm 1.7$ & 0.81 & $21.5 \pm 1.45$ & $22.9 \pm 1.9$ & 0.23 \\
\hline $\begin{array}{c}\text { Monocyte } \\
(\%, \\
\text { mean } \pm \text { SD })\end{array}$ & $4.2 \pm 0.17$ & $4.1 \pm 0.9$ & 0.17 & $4.1 \pm 0.1$ & $4.2 \pm 0.66$ & 0.71 & $3.7 \pm 0.1$ & $3.8 \pm 0.28$ & 0.73 \\
\hline $\begin{array}{c}\text { Eosinophile } \\
(\%, \\
\text { mean } \pm \text { SD) }\end{array}$ & $2.4 \pm 0.87$ & $2.2 \pm 0.74$ & 0.83 & $2.4 \pm 0.7$ & $3.6 \pm 0.09$ & 0.81 & $4.1 \pm 0.2$ & $1.4 \pm 0.7$ & 0.11 \\
\hline ESR $(\%)$ & $30.5 \pm 1.3$ & $21.9 \pm 1.65$ & 0.61 & $10.2 \pm 0.02$ & $6.5 \pm 0.1$ & 0.08 & $62 \pm 2.4$ & $45.9 \pm 2.9$ & 0.34 \\
\hline
\end{tabular}


Table 3: Biochemical parameters at time of incidence and during MPNs therapy.

\begin{tabular}{|c|c|c|c|c|c|c|c|c|c|}
\hline \multirow[b]{2}{*}{ Variables } & \multicolumn{2}{|c|}{ PV } & \multirow[b]{2}{*}{$\begin{array}{c}\mathbf{P} \\
\text { value }\end{array}$} & \multicolumn{2}{|c|}{ ET } & \multirow[b]{2}{*}{$\begin{array}{c}\mathbf{P} \\
\text { value }\end{array}$} & \multicolumn{2}{|c|}{ PMF } & \multirow[b]{2}{*}{$\begin{array}{c}\mathbf{P} \\
\text { value }\end{array}$} \\
\hline & $\begin{array}{l}\text { At time of } \\
\text { diagnosis }\end{array}$ & $\begin{array}{l}\text { During } \\
\text { therapy }\end{array}$ & & $\begin{array}{l}\text { At time of } \\
\text { diagnosis }\end{array}$ & $\begin{array}{l}\text { During } \\
\text { therapy }\end{array}$ & & $\begin{array}{l}\text { At time of } \\
\text { diagnosis }\end{array}$ & $\begin{array}{l}\text { During } \\
\text { therapy }\end{array}$ & \\
\hline $\begin{array}{l}\text { SerumGlucose } \\
(\mathrm{mg} / \mathrm{d}, \mathrm{mean} \pm \mathrm{SD})\end{array}$ & $145 \pm 5.4$ & $110 \pm 5.2$ & 0.6 & $130 \pm 4.7$ & $105 \pm 4.5$ & 0.06 & $119 \pm 4.4$ & $112 \pm 3.1$ & 0.17 \\
\hline $\begin{array}{l}\text { Urea } \\
(\mathrm{mg} / \mathrm{dl}, \mathrm{mean} \pm \mathrm{SD})\end{array}$ & $52.1 \pm 3.5$ & $45.8 \pm 2.7$ & 0.26 & $40.3 \pm 2.2$ & $41.2 \pm 2.6$ & 0.44 & $35.4 \pm 1.8$ & $36.2 \pm 1.1$ & 0.44 \\
\hline $\begin{array}{l}\text { Creatinine } \\
(\mathrm{mg} / \mathrm{dl}, \mathrm{mean} \pm \mathrm{SD})\end{array}$ & $1.3 \pm 0.07$ & $1.12 \pm 0.05$ & 0.44 & $0.99 \pm 0.03$ & $0.9 \pm 0.02$ & 0.45 & $1.0 \pm 0.02$ & $1.1 \pm 0.03$ & 0.54 \\
\hline $\begin{array}{l}\text { Uric acid } \\
(\mathrm{mg} / \mathrm{dl}, \mathrm{mean} \pm \mathrm{SD})\end{array}$ & $6.1 \pm 0.07$ & $5.3 \pm 0.05$ & 0.36 & $4.7 \pm 0.1$ & $4.3 \pm 0.11$ & 0.63 & $5.1 \pm 0.2$ & $4.8 \pm 0.3$ & 0.41 \\
\hline $\begin{array}{l}\text { GOT } \\
(\mathrm{IU} / \mathrm{L}, \mathrm{mean} \pm \mathrm{SD})\end{array}$ & $30.4 \pm 1.0$ & $26.2 \pm 1.1$ & 0.91 & $30.1 \pm 1.3$ & $26.1 \pm 1.2$ & 0.78 & $20.8 \pm 1.01$ & $22.1 \pm 0.9$ & 0.18 \\
\hline $\begin{array}{l}\text { GPT } \\
(\mathrm{IU} / \mathrm{L}, \mathrm{mean} \pm \mathrm{SD})\end{array}$ & $25.9 \pm 1.2$ & $21.3 \pm 1.1$ & 0.01 & $22.1 \pm 1.9$ & $19.4 \pm 1.9$ & 0.83 & $19.8 \pm 1.73$ & $19.5 \pm 1.0$ & 0.32 \\
\hline $\begin{array}{l}\text { Total Bilirubin } \\
(\mathrm{mg} / \mathrm{dl}, \mathrm{mean} \pm \mathrm{SD})\end{array}$ & $0.2 \pm 0.03$ & $0.9 \pm 0.04$ & 0.15 & $0.83 \pm 0.04$ & $0.80 \pm 0.05$ & 0.99 & $0.99 \pm 0.04$ & $1.23 \pm 0.06$ & 0.28 \\
\hline $\begin{array}{l}\text { Direct Bilirubin } \\
(\mathrm{mg} / \mathrm{dl}, \mathrm{mean} \pm \mathrm{SD})\end{array}$ & $0.48 \pm 0.06$ & $0.32 \pm 0.04$ & 0.15 & $0.23 \pm 0.07$ & $0.21 \pm 0.07$ & 0.8 & $0.47 \pm 0.03$ & $0.38 \pm 0.03$ & 0.73 \\
\hline $\begin{array}{l}\text { ALP } \\
(\mathrm{IU} / \mathrm{L}, \mathrm{mean} \pm \mathrm{SD})\end{array}$ & $220.9 \pm 6.9$ & $220.6 \pm 8.2$ & 0.72 & $179.3 \pm 6.4$ & $215 \pm 5.5$ & 0.76 & $149.6 \pm 4.6$ & $151.9 \pm 4.0$ & 0.18 \\
\hline $\begin{array}{l}\text { LDH } \\
(\mathrm{IU} / \mathrm{L}, \mathrm{mean} \pm \mathrm{SD})\end{array}$ & $551 \pm 17.2$ & $458 \pm 15.2$ & 0.39 & $567 \pm 20.3$ & $452 \pm 20.4$ & 0.12 & $498 \pm 18.62$ & $371 \pm 15.0$ & 0.001 \\
\hline $\begin{array}{l}\mathrm{Na}^{+} \\
(\mathrm{mmol} / \mathrm{L}, \mathrm{mean} \pm \mathrm{SD})\end{array}$ & $139 \pm 4.6$ & $139.6 \pm 5.3$ & 0.56 & $142 \pm 4.19$ & $140.2 \pm 3.2$ & 0.29 & $141.3 \pm 4.25$ & $\begin{array}{c}138.1 \pm 3.1 \\
7\end{array}$ & 0.28 \\
\hline $\begin{array}{l}\mathrm{K}^{+} \\
(\mathrm{mmol} / \mathrm{L}, \mathrm{mean} \pm \mathrm{SD})\end{array}$ & $4.44 \pm 0.04$ & $4.6 \pm 0.04$ & 0.88 & $\begin{array}{c}4.83 \pm 0.04 \\
4\end{array}$ & $4.73 \pm 0.06$ & 0.63 & $4.6 \pm 0.07$ & $4.53 \pm 0.06$ & 0.51 \\
\hline $\begin{array}{l}\mathrm{Cl}^{-} \\
(\mathrm{mmol} / \mathrm{L}, \mathrm{mean} \pm \mathrm{SD})\end{array}$ & $109 \pm 3.9$ & $108 \pm 3.1$ & 0.68 & $118 \pm 2.1$ & $110 \pm 1.4$ & 0.26 & $114 \pm 2.7$ & $108 \pm 3.7$ & 0.07 \\
\hline $\begin{array}{l}\mathrm{Ca}^{+2} \\
(\mathrm{mg} / \mathrm{dl}, \mathrm{mean} \pm \mathrm{SD})\end{array}$ & $9.09 \pm 0.09$ & $7.93 \pm 0.3$ & 0.61 & $8.4 \pm 0.09$ & $6.86 \pm 0.01$ & 0.54 & $8.8 \pm 0.01$ & $9.2 \pm 0.08$ & 0.68 \\
\hline $\begin{array}{l}\text { TC } \\
(\mathrm{mg} / \mathrm{dl}, \mathrm{mean} \pm \mathrm{SD})\end{array}$ & $154 \pm 4.4$ & $136.7 \pm 2.3$ & 0.23 & $156 \pm 3.5$ & $167 \pm 3.2$ & 0.4 & $119 \pm 3.73$ & $101.8 \pm 3.9$ & 0.71 \\
\hline $\begin{array}{l}\text { TG } \\
(\mathrm{mg} / \mathrm{dl}, \mathrm{mean} \pm \mathrm{SD})\end{array}$ & $143.2 \pm 2.0$ & $126 \pm 33.7$ & 0.19 & $172 \pm 4.1$ & $134 \pm 3.0$ & 0.78 & $122 \pm 3.1$ & $75.3 \pm 2.1$ & 0.65 \\
\hline $\begin{array}{l}\text { HDL-C } \\
(\mathrm{mg} / \mathrm{dl}, \mathrm{mean} \pm \mathrm{SD})\end{array}$ & $47.3 \pm 1.5$ & $41 \pm 1.4$ & 0.18 & $43.7 \pm 1.9$ & $45.4 \pm 1.3$ & 0.74 & $33.9 \pm 1.34$ & $34.6 \pm 1.6$ & 0.89 \\
\hline $\begin{array}{l}\text { LDL-C } \\
(\mathrm{mg} / \mathrm{dl}, \mathrm{mean} \pm \mathrm{SD})\end{array}$ & $69.4 \pm 1.8$ & $56.3 \pm 1.3$ & 0.21 & $71.9 \pm 1.9$ & $78.3 \pm 1.9$ & 0.22 & $90.8 \pm 1.1$ & $52.1 \pm 1.2$ & 0.1 \\
\hline
\end{tabular}

The mean values of hematological and biochemical parameters were shown in Tables 2 and 3. Values at the time of diagnosis were compared with those during therapy; the PV patients showed significantly higher levels of hemoglobin $(\mathrm{P}<0.003)$, hematocrit $(\mathrm{P}<0.004)$, Neutrophil $(\mathrm{P}<0.001)$, and glutamate pyruvate transferase (GPT) $(\mathrm{P}<0.01)$, in ET patients had significantly $(\mathrm{P}<0.002)$ higher platelet counts, and PMF patients had significantly higher Lactate dehydrogenase level $(\mathrm{P}<0.001)$ and white blood cell count $(\mathrm{P}<0.004)$. These findings were out of the 27 parameters evaluated.

Finally, no significant differences in some hematological and biochemical parameters were observed at the time of diagnosis and during therapy.

\section{Discussion}

The biggest challenge to-date is to find a way for MPNs complete cure but, the goal of therapy is preventing and/ or treating thrombotic events, hemorrhages, and maintaining hematological and biochemical test levels within normal ranges ${ }^{16}$.

When clinicohematological data were compared in different subtype MPNs at time of diagnosis and during thera- py, our study results has shown that treatment of MPNs has variable effects on some hematological and biochemical parameters. Therapy is effective in the prevention of risk factors including thrombotic events. Hemoglobin, Hematocrit, Neutrophil and Glutamate pyruvate transferase levels in PV patients lowered significantly; in ET patients there was a significant reduction in Platelet count, and in PMF patients both Lactate dehydrogenase and White blood cell levels were lowered significantly. These findings in our study are similar to those conducted by Zalcberg et $\mathrm{al}^{17}$ and Soyer $\mathrm{N}$ et $\mathrm{al}^{18}$, who reported that treatment of MPNs was associated with lower blood counts.

Abdullah et $\mathrm{al}^{19}$ conducted a study in Iraq, observed significant differences in WBC, and Plt counts, whereas in $\mathrm{RBC}, \mathrm{PCV}$, and $\mathrm{Hb}$ counts, revealed highly significant differences in MPNs patients. Moreover, our results are in accordance with the previously published study showing in MPN subjects positive for JAK2 V617F mutation an increased chemosensitivity to therapy ${ }^{20}$.

Furthermore, a study conducted by Silva-Pinto et $\mathrm{al}^{21}$, on sickle cell patients revealed that patients presented clinical and hematological improvements after cytoreductive therapy. 
The study results of $\mathrm{Ha}$ JS et $\mathrm{al}^{22}$, disagree with our findings, who reported that treated and untreated ET patients with the JAK2V617F mutation had higher hemoglobin and leukocyte concentrations.

No significant differences in the remaining hematological and biochemical parameters were observed in our study.

The exact mechanism of the therapy remains unknown, but various authors speculate that hydroxyurea causes an immediate inhibition of DNA synthesis by acting as a ribonucleotide reductase inhibitor, without interfering with the synthesis of ribonucleic acid or of protein. Beneficial effects of HU include decreasing neutrophils and increasing the water content of erythrocytes. Alternatively, treatment of MPNs including hydroxyurea has been found to have many various side effects such as granulocytopenia and anemia, especially after long-term therapy ${ }^{23}$. However, inhibitors of the JAK2/STAT pathways cannot be expected to block cytokine production completely and signaling in $\mathrm{MPNs}^{24}$.

Moreover, no significant differences were found in plasma lipid profile, renal function, liver function, and electrolyte tests. These results were similar to results of previous studies ${ }^{25}$. Furthermore, a study by Ginsberg et $\mathrm{al}^{26}$, indicated increased lipid profile levels in MPNs patients after therapy.

\section{Conclusion}

Finally, current therapies for MPNs still need improvement in the area of patient's quality of life, reduction of cardiovascular complications, and prevention of hematological progression. Further studies are required to evaluate the potential for quality of life effects from MPN treatments. A better understanding through clinical and experimental studies of the alterations in the hematological and biochemical values of patients with MPNs is important from a practical point of view and may enable in the planning of more precise treatment.

\section{Conflict of interest}

All authors have no conflict of interest.

\section{References}

1. Tefferi A. Myeloproliferative neoplasms: A deacade of discoveries and treatment advances. Am J Hematol. 2016; 91(1): 50-58.

2. Latagliata R, Spadea A, Cedrone M, Giandomenico JD, De Muro M, Villiva N et al. Symptomatic Mucocu- taneous Toxicity of Hydroxyurea in Philadelphia Chromosome-Negative Myeloproliferative Neoplasms. Cancer. 2012; 118(2): 404-9.

3. Singh A, Xu Y. The Cell Killing Mechanisms of Hydroxyurea. Genes. 2016; 7(99): 1-15.

4. Mishchenko E, Tefferi A. Treatment options for hydroxyurea-refractory disease complications in myeloproliferative neoplasms: JAK2 inhibitors, radiotherapy, splenectomy and transjugular intrahepatic protosystemic shunt. Euro J Haematol. 2010; 85: 192-199. PubMed

5. Langabeer SE, Haslam K. The JAK2 V617F mutation and thrombocytopenia. Hematol Oncol Stem Cell Ther. 2017; 10: 44-45.

6. Cortelazzo S, Finazzi G, Ruggeri M, Vestri O, Galli M, Rodeghiero F et al. Hydroxyurea for patients with essential thrombocythemia and a high risk of thrombosis.

N Engl J Med. 1995; 332: 1132-1137.

7. Lofvanberg E, Wahin A. Management of polycythemia vera, essential thrombocythemia and myelofibrosis with hydroxyurea. European Journal of Haematology. 1988; 41(4): 375-381.

8. Vannucchi AM, Harrison CN. Emerging treatments for classical myeloproliferative neoplasms. Blood. 2017; 129(6): 693-703.

9. Mesa R, Miller CB, Thyne M, Mangan J, Goldberger S, Fazal S et al. Myeloproliferative neoplasms (MPNs) have a significant impact on patients' overall health and productivity: the MPN Landmark survey. BMC Cancer. 2016; 16(167): 1-10.

10. Zalcberg IR, Ayres-Silva J, de Azevedo AM, Solza C, Daumas A, Bonamino M. Hydroxyurea dose impacts hematologic parameters in polycythemia vera and essential thrombocythemia but does appreciably affect JAK2V617F allele burden. Haematologica. 2011; 96(3): e18-e20. PubMed

11. Vannuchi A, Pieri L, Guglielmelli P. JAK2 allele burden in the myeloproliferative neoplasms: effects on phenotype, prognosis and change with treatment. Ther $A d v$ Hemetol. 2011; 2(1): 21-32.

12. Levine R, Pardanani A, Tefferi A, Gilliland DG. Role of JAK2 in the pathogenesis and therapy of myeloproliferative disorders. Nature Reviews Cancer. 2007; 7:673-683. 13. Barbui T, Thiele J, Gisslinger H, Finnazi G, Vannucchi AM, Tefferi A. The 2016 revision of WHO classification of myeloproliferative neoplasms clinical and molecular advances. Blood Rev. 2016; 30(6): 453-459.

14. Jones A. Widespread occurrence of the JAK2V617F 
mutation in chronic myeloproliferative disorders. Blood 2005; 106: 2162-2168. PubMed

15. Daniel WW, Chros CL. Biostatistics: A foundation for analysis in the health sciences. 9th Edition. USA: John Wiley and Sons; 2009.

16. Hasselbalch HC. Perspectives on the impact of JAK-inhibitor therapy upon inflammation-mediated comorbidities in myelofibrosis and related neoplasms. Expert Rev Hematol. 2014; 7(2): 203-216.

17. Zalcberg IR, Ayres-Silva J, de Azevedo AM et al. Hydroxyurea dose impacts hematologic parameters in polycythemia vera and essential thrombocythemia but does not appreciably affect JAK2-V617F allele burden. Haematologica. 2011; 96(3): e18-e20.

18. Soyer N, Haznedaroglu IC, Comert M, Cecdemir D, Yilmaz M, Unal A et al. Multicenter Retrospective Analysis of Turkish Patients with Chronic Myeloproliferative Neoplasms. Turk J Hematol. 2017; 34: 27-33.

19. Abdullah HR, Saifullah PH, Shebib ZA, Abdullah AR. Estimate of JAK2 V617F Mutation and Activity of Catalase Enzyme in Myeloproliferative Neoplasm. Journal of Al-Nabrain University. 2016; 19(3):1-8. PubMed

20. Panova-Noeva M, Marchetti M, Buoro S, Russo L, Leuzzi A, Finazzi G et al. JAK2V617F mutation and hydroxyurea treatment as determinants of immature platelet parameters in essential thrombocythemia and poly- cythemia vera patients. Blood. 2011; 118(9): 2599-2601. PubMed

21. Silva-Pinto AC, Angulo IL, Brunetta DM, Neves FIR, Bassi SC, De Santis GC et al. Clinical and hematological effects of hydroxyurea therapy in sickle cell patients: a single-center experience in Brazil. Sao Paulo Med J. 2013; 131(4): 238-43. PubMed

22. Ha JS, Kim YK, Jung S, Jung HR, Chung IS. Correlations between Janus Kinase 2 V617F Allele Burdens and Clinicohematologic Parameters in Myeloproliferative Neoplasms. Ann Lab Med. 2012; 32: 385-391. PubMed

23. Koc A, Wheeler LJ, Mathews CK, Merrill GF. Hydroxyurea arrests DNA replication by a mechanism that preserves bases dNTP pools. The Journal of Biological Chemistry. 2004; 279: 223-230.

24. Hermouet S, Bigot-Corbel E, and Gardie B. Pathogenesis of Myeloproliferative Neoplasms: Role and Mechanisms of Chronic Inflammation. Mediators of Inflammation. 2015; 2015: 145293.

25. Kuliszkiewicz-Janus M, Malecki R, Mohamed AS. Lipid changes occurring in the course of hematological cancers. Cellular \& Molecular Biology Letters. 2008; 13: 465474.

26. Ginsberg HN, Le NA, Gilbert HS. Altered high density lipoprotein metabolism in patients with myeloproliferative disorders and hypocholesterolemia. Metabolism. 1986; 35: 878-882 